\title{
About Some Problems of the Methodology of the Study of State and Legal Phenomena
}

\section{Vladimir Valentinovich Kozhevnikov}

Department of Theory and History of State and Law, Omsk State University Dostoevsky, Omsk, Russia

Email: kta6973@rambler.ru

\section{Abstract:}

This article is devoted to the problems of the methodology of the study of state and legal problems concerning its "core" - the methods used. Emphasizing the importance of general philosophical (universal, world outlook) methods, the emphasis is placed on the fact that, despite the criticism of Marxist-Leninism, the emergence of new research methods, in Russian jurisprudence, the dialectical-materialist method is the leading general philosophical method.

Keywords:

legal science; methodology; Marxism-Leninism; dialectical-materialistic method

\section{Introduction}

It seems that the relevance of this article is due to the importance of the methodology as a whole and its constituent methods. Francis Bacon compared the method to a lamp illuminating a traveler's path in the dark, and believed that one cannot count on success in studying any issue by going the wrong way. It is generally recognized today that any fruitful research, including in the field of the theory of state and law, inevitably presupposes reliance on well-developed methods of cognition and the corresponding methodology [1].

\section{Research Methods}

When preparing a scientific article, the following methods were used:

1. general philosophical (dialectical-materialistic), which is used in all social sciences;

2. general scientific (analysis and synthesis, logical and historical, comparisons, abstractions, etc.), which are used not only by the theory of state and law, but also by other social sciences;

3. special methods (philological, cybernetic, psychological, etc.), developed by special sciences and widely used for the knowledge of state and legal phenomena;

4. private scientific (formal legal, interpretation of law, etc.), which are developed by the theory of state and law.

\section{Discussion}

\subsection{On the Importance of General Philosophical Methods of Cognition of State and Legal Phenomena}

An analysis of modern domestic legal literature shows that theoretical scientists do not pay due attention to general philosophical methods of understanding state-legal phenomena, limiting themselves to a few sentences when characterizing them or ignoring them altogether. So, Valery Vasilievich Lazarev and Sergey Vasilievich Lipen argue that only general scientific 


\section{Polit Journal: Scientific Journal of Politics \\ ISSN: 2775-5843 (Online), 2775-5835 (Print)}

\section{Vol. 1, No. 2, May 2021, Page: 85-90}

Email: politjournal2@gmail.com

and specific scientific methods of researching state-legal phenomena should be singled out. True, although unreasonably, the authors believe that a certain philosophical trend (materialistic dialectics, neo-Kantianism, neo-Hegelianism, a certain religious ideology, positivism, existentialism, utilitarianism, etc.) acts as general scientific methods, or the methodological basis of research [2] ... At one time, Nikolai Andreevich Pyanov believed that "the modern domestic theory of state and law uses a variety of methods that can be subdivided into general, special and particular" [3]. For the sake of fairness, we note that earlier the scientist, as part of the method of the theory of state and rights, singled out philosophical and worldview approaches as one of their elements, which constitute the methodological basis of the theory of state and law. At the same time, it was emphasized that "in contrast to the Soviet theory of state and law. which was based only on Marxist-Leninist philosophy, the modern Russian theory of state and law is not bound by ideological fetters and, in essence, can (emphasized by us-VK) use any philosophical and worldview approaches "[3]. This position is close to the point of view of Nikolai Nikolaevich Tarasov, who emphasizes that "the overwhelming majority of the fundamental theoretical concepts of Soviet jurisprudence were formed in accordance with the fundamental provisions of the Marxist doctrine and developed within its framework" [4].

It seems that the significance of general philosophical methods is very great. Speaking about philosophical methods (methodological approaches), in the literature, attention was drawn to the fact that such philosophical postulates exist in absolutely any scientific discipline, being present in the course of scientific research quite tangibly as general initial attitudes and universal fundamental principles, which generally form the methodological basis of scientific research [1]. Scientists notice that philosophical methods set only the most general regulations of research, its general strategy, but do not replace special methods and do not determine the final result of cognition directly and directly [5]. Experience shows that "the more general the method of scientific knowledge, the more uncertain it is in relation to the prescription of specific steps of cognition, the greater its ambiguity in determining the final results of research" [6]. But this does not mean that philosophical methods are not at all necessary, for, as the history of knowledge testifies, "an error on the higher levels of knowledge can lead an entire research program to a dead end" [6].

\subsection{On the Content of the Method of Dialectical and Historical Materialism}

Dialectical and historical materialism is a philosophical trend created by Friedrich Engels on the basis of the logic of Georg Wilhelm Friedrich Hegel and the materialism of Ludwig Feuerbach. This method as a theory and method of cognition includes a number of fundamental principles: 1) the principle of the unity of the spiritual and material world, according to which matter is primary in relation to consciousness; 2) the principle of the cognizability of the world, proceeding from the fact that the world around us is cognizable and that the measure of its cognition, which determines the degree of correspondence of our knowledge to objective reality, is social production practice; 3 ) the principle of development, asserting that all phenomena in the world and the world as a whole are in continuous, constant, dialectical development, the source of which is the emergence and resolution of internal contradictions leading to the denial of certain states and the formation of fundamentally new phenomena and processes; 4) the principle of active transformation of the world, based on which, people should not only cognize the world, but also purposefully change it.

According to the materialist understanding of history, the basis of social development is the labor activity of people in the sphere of material production. As production relations change, social institutions change, including the state and law. 
Dialectical logic does not exist outside of materialistic dialectics. It reveals the meaning of the most general laws of the objective world for the movement of thinking towards truth, i.e. is the science of the coincidence of the content of knowledge with the object, reveals the forms of thinking only from the point of view of their structure, without being distracted from the concrete content expressed in them, takes them not in a frozen, not isolated form, but in interconnection, in motion, in development. logic analyzes already established theories, then dialectical logic reveals the logical principles of the transition to new knowledge, explores the formation and development of theory.

The main requirements of dialectical logic are: a) comprehensive coverage of the subject in thinking; b) consideration of the subject in its development, "self-movement"; c) the involvement of all human practice for the complete "definition" of the subject; understanding that there is no abstract truth, truth is always concrete.

Materialistic logic as a method, i.e. dialectical logic, includes:

- general categories, that is, the concept of the most laws of development of nature, society, thinking (for example, "content", "form", "essence", "phenomenon", "cause", "effect");

- categories reflecting specific connections in the process of cognition ("matter" and "consciousness", "empirical" and "theoretical", "abstract" and "concrete", "historical" and "logical");

- the principles of cognition (the unity of the historical and the logical, the ascent from the abstract to the concrete);

- general logical and general scientific methods of cognition (analysis and synthesis, induction and deduction, system and functional analysis, specific sociological analysis).

Supporters of this general philosophical method of cognition of state and legal phenomena and processes believe that the economic basis (content) is the determining reason for the emergence and development of state and law (form). The categories "content" and "form" explain both the dependence of the state and law on the economic basis and their relative independence. In the approach to the concept and essence of state and law, the class approach was decisive, in which the state was viewed as a political organization of the economically dominant class; it is associated with concepts such as a machine to suppres s exploited classes and sectors of society. Law was understood as a class regulator of social relations, with the help of which the ruling class imposes its will on the rest of the classes and strata of society.

\subsection{About the Method of Dialectical and Historical Materialism}

In domestic jurisprudence, a very paradoxical situation has developed: despite the criticism of Marxism-Leninism by modern legal scholars, the method of dialectical and historical materialism, which has made a huge contribution to the knowledge of political and legal reality, is recognized as a general philosophical method. Vyacheslav Nikolayevich Zhukov, referring to this method, writes that at present, to consider the state and law in development, historically, in the unity of the political, spiritual and economic life of society, based on social practice as a criterion of truth has become characteristic of the methodology of theoretical and legal science [7]. At the same time, scientists noticed that, while recognizing pluralism in philosophical and legal concepts, one should always test them for strength, critically assess their heuristic capabilities. Attempts by lawyers to artificially, very arbitrarily combine philosophy and jurisprudence often lead to the construction of speculative schemes (for example, concepts based on phenomenology and existentialism) [7]. 
It seems that the method of dialectical and historical materialism has not lost its relevance in modern legal research. A number of Russian scientists advocate dialecticalmaterialist dialectics. For example, Vladimir Konstantinovich Babaev warned former ardent adherents of Marxist philosophy against yet another extreme and derogatory criticism addressed to it, wrote that foreign sociologists, economists, philosophers, lawyers, Sovietologists, who never accepted Marxism and criticized it, nevertheless treat it with due respect. to him as a teaching, take into account in their studies. So we should act as well, because to reject it completely is just as stupid as to blindly dogmatically confess [8, p.6]. Domestic scientists, in our opinion, quite reasonably declare that today there are no convincing arguments against the use of materialistic dialectics as one of the variants of the theoretical understa nding of the world and elements of the methodology of scientific research. In the modern "philosophical market, it is quite competitive" [9]. American professor Lauren R. Graham believes that "... the dialecticalmaterialist approach — scientifically oriented, realistic, materialistic — claims superiority over existing and competing universal systems of thought, and these claims may be quite justified" [10].

\subsection{Other General Philosophical Methods of Cognition of State and Legal Phenomena and Processes}

We draw your attention to the fact that, in addition to the method of dialectical historical materialism, which is essentially the only method that modern Russian legal scholars prefer, there is a whole system of other general philosophical methods that are based on specific philosophical systems. In this regard, we will name and briefly describe only a few of them. For example, representatives of such a philosophical trend as idealism associate the existence of the state and law with objective reason (objective idealists), or with human consciousness, his experiences, subjective conscious efforts (subjective idealists). Concentrating on the rejection of the domination of the social over the spiritual, subjective idealists argue that it is not external social factors that determine the development of state and law, but the internal spiritual principle contained in the soul of the individual.

Another example is associated with intuitionism - a trend in philosophy that postulates that the only reliable means of knowing both the world around and the human soul is intuition, i.e. a special ability of consciousness, not reducible to either sensory experience or discursive logical thinking. Intuitionism is understood as an idealistic trend, which opposes to rational cognition a direct "comprehension" of reality based on intuition. Let us emphasize that intuitionism directly merges with mysticism.

Intuitiveism is based on the analysis of the holistic problematics of state and law with the help of inspiration. A legal scholar only in a state of mystical union with God can establish what the state and law are.

However, in this case, the following questions naturally arise: what is the mystical connection in this case and what is God for modern researchers of state and rights?

Answering this difficult question, it should be noted that there are many believers in God, mysticism, and their own spiritual inspiration in Russia today.

After the defeat of the Marxist-Leninist ideology in the struggle with other views, they are becoming more and more. It seems that, within the framework of the theory of state and law, it is not enough to consider in general terms the problems of the relationship between the state, religion and church, law and church, and the time has come to more seriously investigate the 
problems of spirituality, state and law, the relationship of various confessions and the state in a multipolar world, understanding believers of the essence, content and tasks of the modern state, their relationship to the rule of law and the observance of these rules.

You can name other general philosophical methods. For example, positivism (lat. positivus - positive) is a direction of philosophy that declares concrete (empirical) sciences to be the only source of true, valid knowledge and denies the cognitive value of philosophical research. Positivist methodology led to the emergence of such varieties of law as legal positivism (analysis of the text of legal acts in isolation from their social content) and sociological positivism (study of state and law in connection with other social phenomena).

The axiological method (from the greek axia - value and logos-doctrine) is an analysis of state and law as specific values, with the help of which a social group or society as a whole regulates the corresponding types of behavior of individuals.

The axiological significance of law is of great scientific, practical and moral significance. It allows you to pay attention not only to the socio-cultural and socio-class foundations and determinants of law, the relationship with the state, but also to its spiritual aspects, the ideals reflected by it. Without a value-based approach, it is impossible to identify the purpose of law in universal human, social and cultural development, to understand its specific nature as a spiritual and practical means of the development of the world by people. Without it, the constructive, creative role of consciousness in the field of law, purely personal aspects of law, remain in the shadows.

Legal axiology is one of the directions of axiology in general, that is, the theory of values, the theory of generally valid principles that determine human activity, the motivation of behavior. The theory of values (axiology) finds corresponding application in the field of law. Legal values and assessments (in the field of legal awareness) have regulatory significance. Legal norms, in turn, acquire the meaning of values and become an object of evaluation.

\section{Conclusion}

In the final part of the article, it is necessary to summarize that, despite the criticism of the Marxist-Leninist doctrine, the emergence of new research methods, the method of materialist dialectics is the leading general philosophical method in the study of state-legal phenomena.

In modern conditions, many former supporters of Marxism-Leninism have revised their views on the philosophical foundations of the theory of state and law, prefer to talk about the totalitarian thinking characteristic of this concept, forgetting that this approach contains many ideas that have justified themselves in practice. These include, for example, the study of specific social phenomena in connection with other phenomena (economy, politics, morality, culture, etc.), taking into account the specific conditions of their existence and development. Nowadays it is becoming clear to many that the fight against totalitarianism in the field of science should not be transformed into a new totalitarianism, which consists in an unjustified rejection of everything that may resemble the past.

\section{References}

[1]. Kozhevnikov Vladimir Valentinovich, Senin Igor Nikolaevich. Methodology of the theory of state and law: textbook. Omsk: Omsk Economic Institute, 2013. Pp. 7, 49. 
[2]. Lazarev Valery Vasilievich, Lipen Sergey Vasilievich Theory of state and law: textbook. Moscow: Yurayt, 2019. P. 22.

[3]. Pyanov Nikolai Andreevich. Consulting on the theory of state and law: textbook. Irkutsk, Publishing house of the Irkutsk state. University, 2010.Pp. 19-20.

[4]. Tarasov Nikolay Nikolaevich. Methodological problems of legal science. Yekaterin burg: Publishing house of the Humanitarian University, 2001. P.29.

[5]. Kokhanovsky Valery Pavlovich, Leshkevich Tatiana Gennadievna, Matyash Tamara Petrovna, Fatkhi Tatiana Borisovna. Fundamentals of the philosophy of science: textbook. Rostov n / a: Phoenix, 2010.P. 318.

[6]. Kravets Alexander Samuylovich. Methodology of Science. Voronezh: Voronezh University, 1991.Pp. 13, 15.

[7] Zhukov Vyacheslav Nikolaevich. Philosophy of law: textbook. M .: World of Philosophy, Algorithm, 2019.Pp. 37, 39.

[8]. General theory of law: a course of lectures / ed. Vladimir Konstantinovich Babaev. N. Novgorod: Nizhny Novgorod High School of the Ministry of Internal Affairs of Russia, 1993. P.6.

[9]. Baranov Vladimir Mikhailovich, Pershin Victor Borisovich, Baranova Marina Vladimirovna. The place and role of the method of materialistic dialectics in legal research // Philosophy of law. 2007. No. 3. P.10.

[10]. Graham Lauren R. Natural Science, Philosophy and Science of Human Behavior in the Soviet Union. M .: Politizdat., 1991. P.15. 